\title{
Effectiveness of microbial preparations in growing Cicer arietinum L. in the steppe zone of the Crimea
}

\author{
$S V$ Didovich $^{1, *}, O P$ Ptashnik $^{1}$, and $V S$ Pashtetskiy $^{1}$ \\ ${ }^{1}$ Research Institute of Agriculture of Crimea, 150 Kievskaya str., Simferopol, 295493, Russia
}

\begin{abstract}
Currently, the main priorities in agricultural production are ecologization, rational use of natural resources, resource-conservation and economic practicability. Therefore, biotechnologies for growing agricultural crop develop. The article presents the results of effectiveness of pre-sowing treatment with polyfunctional microbial preparations compared to the use of mineral fertilizer Ammophos in growing Cicer arietinum L. in the steppe zone of the Crimea on non-irrigated southern Chernozem in 2015-2017. Weather conditions during the growing season and treatment with microbial preparations, as well as the use of mineral fertilizers, affected seed productivity of chickpeas in the time of research. On average, for three years, bacterization with Rhizobofit, Cyano-rhizobial consortium and complex Rhizobofit + Phosfoenterin + Biopolicyd significantly increased 1000 seeds weight and seed yield by $16.67 \mathrm{~g}(6.7 \%)$ and $0.15 \mathrm{t} / \mathrm{ha}(10.8 \%) ; 27.27 \mathrm{~g}(9.8 \%)$ and $0.1 \mathrm{t} / \mathrm{ha}(7.2 \%) ; 14.14 \mathrm{~g}(5.5 \%)$ and $0.22 \mathrm{n} / \mathrm{ha}(15.1 \%)$, respectively, compared to the Ammophos application in dose N30P30 (Duncan's test p $<0,000121$ ). These preparations are recommended for biologised agrotechnology for growing chickpea in the steppe zone of the Crimea and obtaining ecologically safe production.
\end{abstract}

\section{Introduction}

Chickpea (Cicer arietinum L.) is the oldest crop of the world agriculture. It occupies the third place in the world of the total cultivated area among grain legumes (12 million ha). According to Russian Statistics, chickpea occupy 30.6\% (850.2 thousand ha) of the total area of legumes in Russia [1]. The sown area of chickpea has grown by $71.6 \%(355.2$ thousand ha) over the year, by $26.5 \%$ (178.1 thousand ha) compared to 2013 . The main producers of chickpeas are Saratov region (266.6 thousand ha), Volgograd region (191.3 thousand ha), Orenburg region (114.6 thousand ha), Samara region (88.5 thousand ha), Rostov region (74.1 thousand ha) and others. In the Crimea, the sown area of chickpea does not exceed 15 thousand ha.

Chickpea is crop with low demands for water and with great drought resistance [2]. The plants are tolerant to high temperatures, dry winds, dust storms, hail. This is cold-resistant

\footnotetext{
*Corresponding author: didovich_s@ @ niishk.ru
} 
agricultural crop. The chickpea forms a symbiotic relationship with nodule bacteria of the species Mesorhizobium ciceri and can assimilate to $125-150 \mathrm{~kg} / \mathrm{ha}$ of nitrogen from the air annually, meet the needs for this element by $60-90 \%$ and leave to $25-45 \%$ of the symbiotic nitrogen in the soil with crop residues for subsequent agricultural crops [3]. The aftereffect of symbiotrophic nitrogen after chickpea is equivalent to $100 \mathrm{~kg} / \mathrm{ha}$ of ammonium nitrate.

In Russia, there is a long-term practice of application different biopreparations based on symbiotic nitrogen-fixing nodule bacteria in the cultivation of legumes [4-6]. This is very important for growing chickpeas. There are no any indigenous populations of Mesorhizobium ciceri - native chickpea's symbionts - in steppe zone of the Crimea [7]. Pre-sowing treatment of chickpea seeds with microbial preparations based on highly effective rhizobia strains should be used for the effective process of biological nitrogen fixation and increasing the productivity of plants. The biotechnology of the chickpea growing was developed on the strategies of the joint using of the strains of the heterotrophic microorganism with different functions (symbiotic nitrogen-fixing, phosphate-mobilizing, growth-promoting activities, antagonistic activity to phytopathogens, entomocide activity to phytophagens). The studies of the phototrophic soil cyanobacteria deserve the special attention. Cyanobacteria form constant and active part of the soil biota, interact with its components and take part in a different process in the soil. Thusfore, cyanobacteria have great potential in agricultural practice [8-10].

Thus, the aim of our research was to study the influence of microbial preparations based on heterotrophic and phototrophic microorganism on seed productivity of chickpea in the steppe zone of the Crimea.

\section{Methods and conditions}

The research was carried out in 2015-2017 in the experimental plots in the steppe zone of the Crimea on southern Chernozem, with the presence of humus 2.2-2.3\%. The thickness of the humus layer is $50 \mathrm{~cm}$. The arable soil layer $(0-20 \mathrm{~cm})$ was characterized by high availability of exchangeable potassium $(32-36 \mathrm{mg} / 100 \mathrm{~g}$ of soil), average availability of mobile phosphorus (4.6-6.0 mg/100 g of soil) and low availability of easily hydrolyzed nitrogen $(3.0-4.0 \mathrm{mg} / 100 \mathrm{~g}$ of soil), the reaction of soil solution $\mathrm{pH}$ 7.5. Agrochemical parameters of soils were determined using standard methods: humus by Tyurin, mobile phosphorus $\left(\mathrm{P}_{2} \mathrm{O}_{5}\right)$ and exchangeable potassium $\left(\mathrm{K}_{2} \mathrm{O}\right)$ by Machigin. The easily hydrolyzed nitrogen was determined according to GOST 26213-91 [11].

Microbial preparations for the experiments were made in the Department of Agricultural Microbiology of Federal State Budget Scientific Institution "Research Institute of Agriculture of Crimea" (Simferopol). Rhizobofit (R) is a microbial preparation based on symbiotic nitrogen-fixing nodule bacteria of the species Mesorhizobium ciceri. Phosfoenterin $(\mathrm{Ph})$ is a preparation based on phosphate-mobilizing strain Lelliottia nimipressuralis. Biopolicyd (B) is a microbial preparation based on the antagonist of phytopathogens strain Paenibacillus polymyx. Cyano-rhizobial consortium (CRC) is a microbial preparation based on a specific strain of rhizobia Mesorhizobium ciceri and phototrophic nitrogen-fixing strain of cyanobacteria Nostoc linckia with 12 different functioning associative to this cyanobacteria strains. All used strains are plant growthpromoting bacteria. The biopreparations were used for pre-sowing treatment of chickpea seeds in an amount of $2.0 \%$ of the working solution by seeds weight [12-13]. As a control, the variant with application of mineral fertilizer Ammophos in dose of $\mathrm{N}_{30} \mathrm{P}_{30}$ before sowing.

Chickpea variety Zolotoy jubilee was studied in our experiments. The experiments are based on three replications, with a plot area of 25 square meters, were carried out by common methods [14]. 
Agro-climatic conditions of steppe zone are characterized by unstable and insufficient moisture, with a mean annual rainfall of 340-418 millimeters and a mean annual air temperature of $9.8-10.4^{\circ} \mathrm{C}[15]$.

During the years of the experiments, the weather conditions were different. The amount of active air temperature in the growing seasons 2015 was $1321.4^{\circ} \mathrm{C}$, which was higher by $29.7^{\circ} \mathrm{C}$ compared to the long-time average annual rate for the similar period. The amount of precipitation was $336.5 \mathrm{~mm}$, which was 1.9 times higher than the long-time average annual value $(176 \mathrm{~mm})$. Hydrothermal index was at the level of 2.54 .

The amount of active air temperature in the growing season 2016 was $1547.2^{\circ} \mathrm{C}$, which was higher than the long-time average annual air temperature by $255.5^{\circ} \mathrm{C}$. The amount of precipitation was 2.6 times higher than the long-time average annual value and reached $457.5 \mathrm{~mm}$. Hydrothermal index was at the level of 2.95 .

In 2017 , the amount of active air temperature was $1373.4^{\circ} \mathrm{C}$, which was higher than the long-time average annual by $82.5^{\circ} \mathrm{C}$, however the amount of precipitation was $59.2 \mathrm{~mm}$ $(66.3 \%)$ less than norm. Hydrothermal index was at the level of 1.04 .

Statistical processing of the research results was carried out by the method of dispersion analysis (ANOVA) using the software Statistica 10.

\section{Results and discussion}

The influence of the microbial preparations on such chickpea parameters as number of seeds per plant, 1000 grains weight and seed yield were studied in the steppe zone of the Crimea.

The parameter of the number of seeds in control was amounted 36.25 seeds per plant in 2015, 32.00 seeds per plant in 2016 and 25.00 seeds per plant in 2017 (Fig. 1). In 2016, seeds bacterization with Rhizobofit and Cyano-rhizobial consortium significantly increased this indicator by $9.25(28.90 \%)$ and 17.25 seeds per plant $(53.90 \%)$ compared to the variant with the mineral fertilizer Ammophos $(\mathrm{p}<0.05)$. 

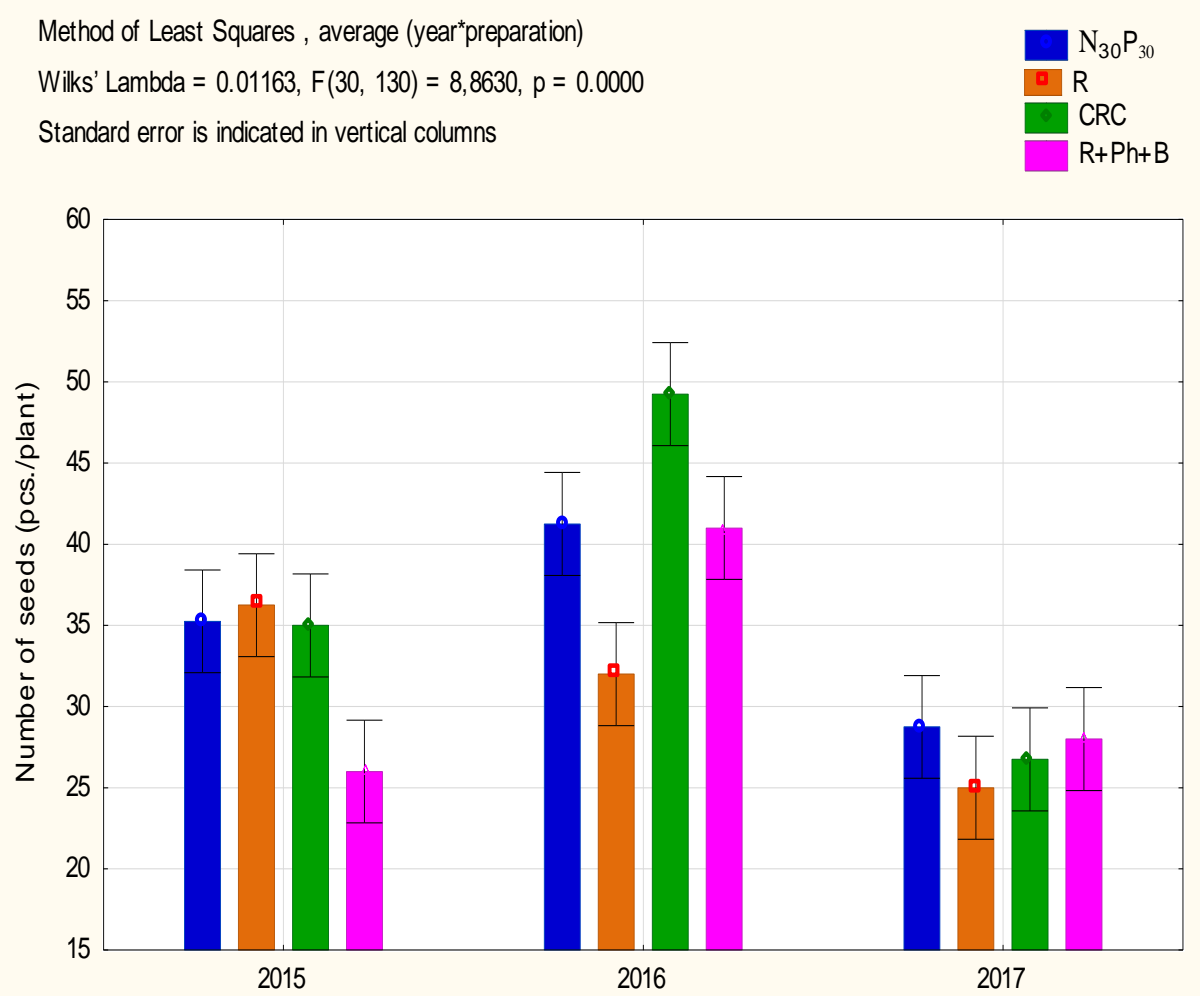

Fig. 1. Influence of seeds bacterization by microbial preparation on the number of seeds (pcs./plant): N30P30 - mineral fertilizer Ammophos in dose of N30P30, R - Rhizobofit, CRC - Cyano-rhizobial consortium, $\mathrm{Ph}$ - Phosfoenterin, B - Biopolicyd.

On average, for three years, according to conservative posteriori Duncan's test, microbial treatment of seeds with Cyano-rhizobial consortium significantly increased the number of seeds per plant, namely by 5.92 seeds per plant $(16.4 \%)$ compared to the variant with Ammophos ( $\mathrm{p}=0,041823)$ (Table 1).

Table 1.Approximate probabilities for a posteriori Duncan's test to number of seeds on average, for 2015-2017.

\begin{tabular}{|c|c|c|c|c|}
\hline Variants of experiments & $\begin{array}{c}\mathrm{N}_{30} \mathrm{P}_{30}, \\
31.08^{*} \\
\text { (pcs./plant) }\end{array}$ & $\begin{array}{c}\mathrm{R}, \\
35.08^{*} \\
\text { (pcs./plant) }\end{array}$ & $\begin{array}{c}\mathrm{CRC}, \\
37.00^{*} \\
\text { (pcs./plant) }\end{array}$ & $\begin{array}{c}\mathrm{R}+\mathrm{Ph}+\mathrm{B}, \\
31.67^{*} \\
\text { (pcs./plant) }\end{array}$ \\
\hline $\mathrm{N}_{30} \mathrm{P}_{30}$ & 0,152781 & - & 0,041823 & 0,823051 \\
\hline $\mathrm{R}$ & - & 0,152781 & 0,463844 & 0,195173 \\
\hline $\mathrm{CRC}$ & 0,463844 & 0,041823 & - & 0,057962 \\
\hline $\mathrm{R}+\mathrm{Ph}+\mathrm{B}$ & 0,195173 & 0,823051 & 0,057962 & - \\
\hline \multirow{2}{*}{ - number of seeds for three years on average, significant pair comparisons are highlighted in red, } \\
$\mathrm{N}_{30} \mathrm{P}_{30}-$ mineral fertilizer Ammophos in dose of $\mathrm{N}_{30} \mathrm{P}_{30}, \mathrm{R}-$ Rhizobofit, CRC - Cyano-rhizobial \\
consortium, Ph - Phosfoenterin, B - Biopolicyd.
\end{tabular}

1000 grains weight in the control variant reached $296.5 \mathrm{~g}$ in $2015,214.5 \mathrm{~g}$ in 2016 and $241.0 \mathrm{~g}$ in 2017 (Figure 2). In 2015, seeds treatment with Rhizobofit, Cyano-rhizobial consortium and complex Rhizobofit + Phosfoenterin + Biopolicyd significantly increased this indicator by $43.3 \mathrm{~g}(14.6 \%), 35.3 \mathrm{~g}(11.9 \%)$ and $30.5 \mathrm{~g}(10.3 \%)$ compared to the 
variant with a mineral fertilizer Ammophos $(\mathrm{p}<0.05)$. In 2016, seeds bacterization with the same preparations increased 1000 grains weight by $16.8 \mathrm{~g}(7.8 \%), 27.5(12.8 \%)$ and $10.0 \mathrm{~g}$ $(4.5 \%)$ compared to the control, respectively $(p<0.05)$. In 2017 , use of complex Rhizobofit + Phosfoenterin + Biopolicyd significantly increased 1000 grains weight by $19.0 \mathrm{~g}(7.9 \%)$ compared to control $(\mathrm{p}<0.05)$.

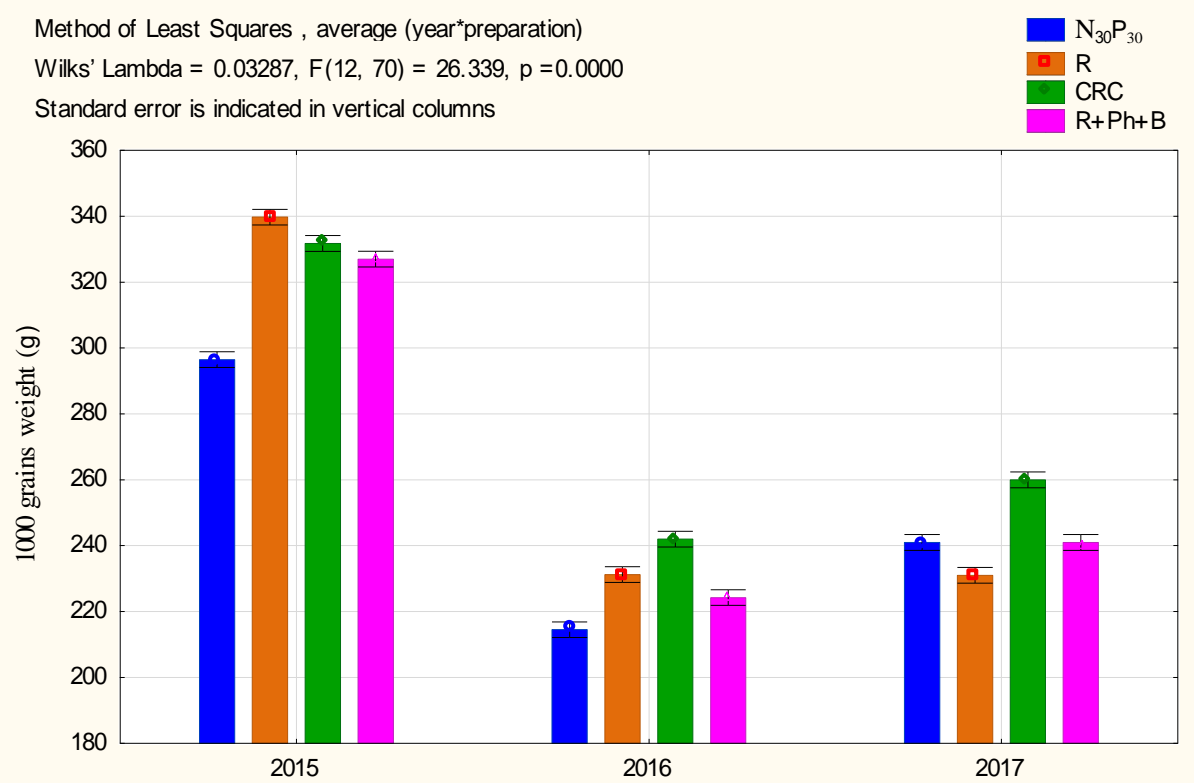

Fig. 2. Influence of seeds bacterization by microbial preparation on the 1000 grains weight (g): $\mathrm{N}_{30} \mathrm{P}_{30}$ - mineral fertilizer Ammophos in dose of $\mathrm{N}_{30} \mathrm{P}_{30}, \mathrm{R}$ - Rhizobofit, CRC - Cyano-rhizobial consortium, $\mathrm{Ph}$ - Phosfoenterin, B - Biopolicyd.

On average, for three years, according to conservative posteriori Duncan's test of ANOVA, microbial treatment of seeds with Cyano-rhizobial consortium contributed to a significant increase in 1000 grains weight by $27.3 \mathrm{~g}(9.8 \%)$ compared to the variant with mineral fertilizer Ammophos $(\mathrm{p}=0,000053)$; by $10.6 \mathrm{~g}(4.0 \%)$ than in the variants with Rhizobofit $(p=0.000124)$, but did not practically differ from complex Rhizobofit + Phosfoenterin + Biopolicyd ( $\mathrm{p}=0.000063)($ Table 2).

Table 2. Approximate probabilities for a posteriori Duncan's test to the 1000 grains weight on average, for 2015-2017.

\begin{tabular}{|c|c|c|c|c|}
\hline $\begin{array}{l}\text { Variants of } \\
\text { experiments }\end{array}$ & $\begin{array}{c}\mathrm{N}_{30} \mathrm{P}_{30} \\
250.67 *(\mathrm{~g})\end{array}$ & $\begin{array}{c}\mathrm{R}, \\
267.33^{*}(\mathrm{~g})\end{array}$ & $\begin{array}{c}\text { CRC, } \\
277.92 *(\mathrm{~g})\end{array}$ & $\begin{array}{c}\mathrm{R}+\mathrm{Ph}+\mathrm{B}, \\
264.08^{*}(\mathrm{~g})\end{array}$ \\
\hline $\mathrm{N}_{30} \mathrm{P}_{30}$ & - & 0,000063 & 0,000053 & 0,000121 \\
\hline $\mathrm{R}$ & 0,000063 & - & 0,000124 & 0,105135 \\
\hline $\mathrm{CRC}$ & 0,000053 & 0,000124 & - & 0,000063 \\
\hline $\mathrm{R}+\mathrm{Ph}+\mathrm{B}$ & 0,000121 & 0,105135 & 0,000063 & - \\
\hline \multicolumn{5}{|c|}{$\begin{array}{l}* 1000 \text { grains weight for three years on average, significant pair comparisons are highlighted it } \\
\text { red, } \mathrm{N}_{30} \mathrm{P}_{30}-\text { mineral fertilizer Ammophos in dose of } \mathrm{N}_{30} \mathrm{P} \mathrm{P}_{30}, \mathrm{R} \text { - Rhizobofit, CRC - Cyano- } \\
\text { rhizobial consortium, } \mathrm{Ph}-\text { Phosfoenterin, } \mathrm{B} \text { - Biopolicyd. }\end{array}$} \\
\hline
\end{tabular}

Maximum seed yield in control was $1.79 \mathrm{t} / \mathrm{ha}$ in arid 2017; low seed yield amounted 1.0-1.4 t/ha in moisture 2015 and 2016 (Fig. 3). 

Method of Least Squares, average (year"preparation)
Wilks' Lambda $=0.03287, F(12,70)=26.339, p=0.0000$

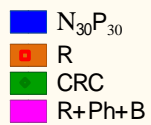
Standard error is indicated in vertical columns

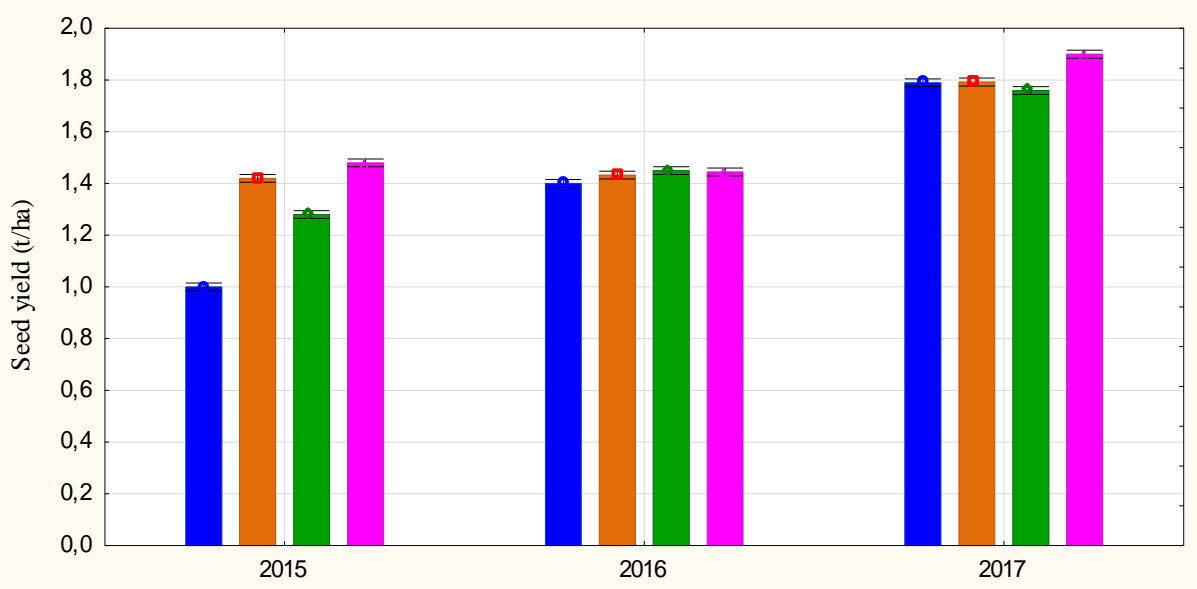

Fig. 3. Influence of seeds bacterization by microbial preparation on the seed yield ( $t / h a): \mathrm{N}_{30} \mathrm{P}_{30}-$ mineral fertilizer Ammophos in dose of $\mathrm{N}_{30} \mathrm{P}_{30}, \mathrm{R}$ - Rhizobofit, CRC - Cyano-rhizobial consortium, $\mathrm{Ph}$ - Phosfoenterin, B - Biopolicyd.

According to the results of the experiment, the effectiveness of bacterization varied during the years of research. In 2015, seeds treatment with Rhizobofit, Cyano-rhizobial consortium and complex Rhizobofit + Phosfoenterin + Biopolicyd contributed to increase in seed yield by $0.42 \mathrm{t} / \mathrm{ha}(42.0 \%), 0.28 \mathrm{t} / \mathrm{ha}(28.0 \%)$ and $0.48 \mathrm{t} / \mathrm{ha}(48.0 \%)$ compared to the variant with the mineral fertilizer $(\mathrm{p}<0.05)$.

In 2016, significant increase was in the variants with complex Rhizobofit + Phosfoenterin + Biopolicyd and Cyano-rhizobial consortium and amounted 0.04-0.05 t/ha (2.9-3.6\%) compared to control (Fisher's test $\mathrm{p}=0.02$ and $\mathrm{p}=0.04$ ).

In 2017, seed treatment with complex Rhizobofit + Phosfoenterin + Biopolicyd contributed to increase in seed yield by $0.11 \mathrm{t} / \mathrm{ha}(6.1 \%)$ compared to the variant with Ammophos (Fisher's test $\mathrm{p}=0.000009$ ).

On average, for three years, according to conservative posteriori Duncan's test of ANOVA, bacterization with Cyano-rhizobial consortium, Rhizobofit and complex Rhizobofit + Phosfoenterin + Biopolicyd significantly increased seed yield by $0.1,0.15$ and $0.22 \mathrm{t} / \mathrm{ha}(7.2,10.8$ and $15.1 \%)$ compared to control $(\mathrm{p}=0.000121,0.000063$ and 0.000053 ) (Table 3).

Table 3. Approximate probabilities for a posteriori Duncan's test to the seed yield on average, for 2015-2017.

\begin{tabular}{|c|c|c|c|c|}
\hline Variants of experiments & $\begin{array}{c}\mathrm{N}_{30} \mathrm{P}_{30} \\
1.39 *(\mathrm{t} / \mathrm{ha})\end{array}$ & $\begin{array}{c}\mathrm{R}, \\
1.55^{*}(\mathrm{t} / \mathrm{ha})\end{array}$ & $\begin{array}{c}\text { CRC, } \\
1.49^{*}(\mathrm{t} / \mathrm{ha})\end{array}$ & $\begin{array}{c}\mathrm{R}+\mathrm{Ph}+\mathrm{B}, \\
1.61 *(\mathrm{t} / \mathrm{ha})\end{array}$ \\
\hline $\mathrm{N}_{30} \mathrm{P}_{30}$ & - & 0,000063 & 0,000121 & 0,000053 \\
\hline $\mathrm{R}$ & 0,000063 & - & 0,000278 & 0,000139 \\
\hline CRC & 0,000121 & 0,000278 & - & 0,000063 \\
\hline $\mathrm{R}+\mathrm{Ph}+\mathrm{B}$ & 0,000053 & 0,000139 & 0,000063 & - \\
\hline \multicolumn{5}{|c|}{$\begin{array}{c}* \text { - seed yield for three years on average, significant pair comparisons are highlighted in red, } \\
\mathrm{N}_{30} \mathrm{P}_{30}-\text { mineral fertilizer Ammophos in dose of } \mathrm{N}_{30} \mathrm{P}_{30}, \mathrm{R}-\text { Rhizobofit, CRC - Cyano-rhizobial } \\
\text { consortium, } \mathrm{Ph}-\text { Phosfoenterin, } \mathrm{B} \text { - Biopolicyd. }\end{array}$} \\
\hline
\end{tabular}


The climate conditions had the large temperature contrast in the studied years. Climatic conditions of steppe zone affected seed productivity of chickpea (Table 4). A significant difference was found in the yield structure at the level of the Duncan's test $(p<0,0112)$.

Table 4. Approximate probabilities for a posteriori Duncan's test to the seed productivity on average, for the variants of seeds treatment and application fertilizers Ammophos by years.

\begin{tabular}{|c|c|c|c|c|c|c|c|c|c|}
\hline \multirow{3}{*}{ Parameters } & \multicolumn{3}{|c|}{ Number of seeds } & \multicolumn{3}{|c|}{1000 grains weight on } & \multicolumn{3}{|c|}{ Seed yield on average } \\
\hline & \multicolumn{3}{|c|}{ on average (pcs./plant) } & \multicolumn{3}{|c|}{ average $(\mathrm{g})$} & \multicolumn{3}{|c|}{ (t/ha) } \\
\hline & 33.13 & 40.88 & 27.13 & 323.75 & 228.00 & 243.25 & 1.29 & 1.43 & 1.81 \\
\hline Years & 2015 & 2016 & 2017 & 2015 & 2016 & 2017 & 2015 & 2016 & 2017 \\
\hline 2015 & ' & $\frac{n}{8}$ & $\begin{array}{l}\stackrel{I}{\Xi} \\
\stackrel{0}{0}\end{array}$ & ' & 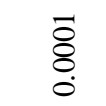 & $\begin{array}{l}\overline{8} \\
8 \\
0\end{array}$ & ' & $\overline{8}$ & 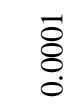 \\
\hline 2016 & $\begin{array}{l}\frac{n}{8} \\
\stackrel{0}{0}\end{array}$ & 1 & $\begin{array}{l}\overline{8} \\
\overline{0}\end{array}$ & $\begin{array}{l}\overline{8} \\
\text { o } \\
\end{array}$ & ' & 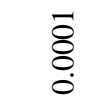 & $\begin{array}{l}\overline{8} \\
\\
0\end{array}$ & ' & $\begin{array}{l}\overline{8} \\
8 \\
\end{array}$ \\
\hline 2017 & $\begin{array}{l}\stackrel{ }{\Xi} \\
\stackrel{0}{0}\end{array}$ & $\begin{array}{l}\overline{8} \\
\dot{8}\end{array}$ & ' & $\begin{array}{l}\overline{8} \\
\dot{8}\end{array}$ & $\begin{array}{l}\overline{8} \\
8 \\
0\end{array}$ & ' & $\begin{array}{l}\overline{8} \\
8 \\
0\end{array}$ & $\overline{8}$ & ' \\
\hline & & & & & & & & & \\
\hline
\end{tabular}

* Significant pair comparisons are highlighted in red.

Climatic conditions of 2015 and 2016 were optimum for the formation of the number of seeds. Lack of moisture in 2017 affected the number of seeds which was 1.2-1.5 time lower than average parameters in 2015 and 2016. In 2015, rainfall during the ripening stage made it difficult to harvest crop. Waterlogging of the soil during growing seasons 2016 caused chickpea diseases and influenced 1000 grains weight and seed yield. Low seed yield was in 2015 (1.29 t/ha) and in 2016 (1.43 t/ha). In 2017, the excess of air temperature was combined with small amount of rain. In addition, precipitation fell during the period of intensive plant growth. These climatic conditions influenced seed yield of chickpea, which was maximum and amounted $1.81 \mathrm{t} / \mathrm{ha}$.

\section{Conclusion}

Thus, the effectiveness of microbial preparations in growing chickpea in the steppe zone of the Crimea in 2015-2017 was shown. Weather conditions during the growing season and treatment with microbial preparations, as well as the use of mineral fertilizers affected seed productivity of chickpeas during the years of research. On average, for three years, presowing treatment of chickpea seeds with polyfunctional microbial preparations contributed to a significant increase in 1000 grains weight by 14.14-27.3 g (5.5-9.8\%) and seed yield by $0.1-0.22 \mathrm{t} / \mathrm{ha}(7.2-15.1 \%)$ compared to the variant with mineral fertilizer Ammophos (Duncan's test $\mathrm{p}<0,000121$ ). Rhizobofit, Cyano-rhizobial consortium and complex Rhizobofit + Phosfoenterin + Biopolicyd are recommended for growing chickpea in the steppe zone of the Crimea for biologized agrotechnology for growing chickpea and obtaining ef ecologically safe production. 


\section{References}

1. 2020 Bulletins on the state of agriculture (electronic versions) Catalog of publications of the Federal State Statistics Service (Moscow: Federal State Statistics Service)

2. Bushulyan O V, Sichkar V I 2009 Chickpea: genetics, selection, breeding, technology of growing: Monography (Odessa) p 248

3. Babich A O, Petrichenko V F, Adamen F F 1996 The problem of photosynthesis and biological fixation of nitrogen by legumes Bulletin of agricultural science 2 (514) 3439

4. Kokorina A L, Kozhemyakov A P 2010 Bean-rhizobial symbiosis and application of microbiological preparations of complex action - an important reserve for increasing productivity of arable land (Saint-Petersburg) p 50

5. Zavalin A A 2005 Biopreparations, fertilizers and yield (Moscow) p 302

6. Tikhonovich I A, Borisov A Yu, Vasilchikov A G, Zhukov V A, Kozhemyakov A P, Naumkina T S, Chebotar V K, Shtark O Yu, and Yakhno V V 2012 Specificity of microbiological preparations for legumes and features of their production Legumes and cereals 3 11-17

7. Didovich S V 2013 Ecological safe growing of chickpea in area of Steppe of Ukraine Journal of Life science 7 (11) 1184-1189

8. Kaushik B D 2014 Developments in cyanobacterial biofertilizer Proc. Indian Natn. Sci. Acad. 80 (2) 379-388

9. Singh H, Khattar J S and Ahluwalia A S 2014 Cyanobacteria and agricultural crops Vegetos-An International Journal of Plant Research 27 (1) 37-44

10. Prasanna R, Sood A, Ratha S K and Singh P K 2014 Cyanobacteria as a "green" option for sustainable agriculture ed Naveen K Sharma, Ashwani K Rai and Lucas J Sta Cyanobacteria: an economic perspective (9) 145-166

11. GOST 33980-2016 Organic production. Production regulations, processing, labelling and implementation (Moscow: FSUE STANDARTINFORM)

12. Volkogon V V, Nadkernychna O V, Tokmakova L N 2010 Experimental soil microbiology (Kiev: Agrarna nauka) p 464

13. Khotyanovich A V 1991 Methods for cultivation of nitrogen-fixing bacteria, methods of production and application of preparations on their basis (Leningrad) p 60

14. Dospekhov B A 2011 Methods of field research (Moscow)

15. Polovitsky I Ya and Gusev P G 1987 Soils of Crimea and increase of their fertility: Reference edition (Simferopol: Tavria) p 152 